\title{
MigRación INTERNACIONAL INDÍGENA Y VULNERABILIDAD ANTE EL VIH-SIDA. LOS CHAMULAS ENTRE BARRAS Y ESTRELLAS
}

\author{
Juan Carlos García Sosa \\ Sergio Meneses Navarro \\ Sebastiana Palé Pérez
}

\begin{abstract}
Resumen: Este articulo presenta testimonios de la experiencia de indigenas chamulas con relación al proceso migratorio hacia los Estados Unidos de América. Elpropósito es identificar las condicionesy las prácticas que colocan a los migrantes y a sus familias ante el peligro de contraer infecciones de transmisión sexual, particularmente el VIH-SIDA. El marco de referencia propuesto se basa en los conceptos de vulnerabilidad y prácticas de riesgo, los cuales sirven para ordenar la reflexión acerca del impacto de la migración sobre la salud sexual de los chamulas. Tales conceptos permiten hacer una reflexión amplia del tema y a través de ella se identifican diversas vetas de análisis sobre las que es necesario profundizar. De esta manera, el articulo presenta un fenómeno que se ha estudiado poco en la región y deja sobre la mesa información relevante para enriquecer la discusión acerca la migración y sus efectos en el ámbito local.
\end{abstract}

Palabras clave: proceso migratorio, prácticas de riesgo, vulnerabilidad, infecciones de transmisión sexual, VIH-SIDA.

Enviado a dictamen: 13 de febrero de 2006.

Aprobación: 09 de abril de 2007.

Juan Carlos García Sosa, antropólogo (UV), maestro en antropología social con área de concentración en antropología médica (CIESAS-Sureste). Actualmente, alumno del Doctorado en Ciencias Antropológicas (UAMIztapalapa), correo electrónico: genmagico@hotmail.com.

Sergio Meneses Navarro, médico (UAM-X), maestro en antropología social con área de concentración en antropología médica (CIESAS-Sureste). Actualmente, alumno del Doctorado en salud pública (INSP), correo electrónico: sergiomenesesn@prodigy.net.mx.

Sebastiana Palé Pérez, traductora e investigadora de campo, CIESAS-Sureste.
Abstract: This article presents testimonies of the experiences of indigenous people from Chamula in relation to the process of migration to the United States of America. The goal is to identify the conditions and the practices that place migrants and their families in danger of acquiring sexually transmitted infections, in particular HIV-AIDS. The guiding conceptual references are vulnerability and risk practices which serve to order the reflection surrounding the impact of migration on sexual health in Chamula. These concepts allow us to reflect in a general manner on the issue and to identify diverse analytical topics that then need to be elaborated upon. In this manner, the article presents a phenomenon that has not been well studied in the region and offers relevant information with which to enrich the discussion of migration and its effects on the local level.

Key Words: migratory process, risk behavior, vulnerability, sexually transmitted infections, HIV/AIDS.

\section{Introducción}

$\mathrm{L}$ a migración internacional en el estado de Chiapas en general, y en el municipio de San Juan Chamula en particular, es un fenómeno que recientemente se ha incrementado. Sin embargo, para los habitantes de este municipio indígena enclavado en la región de Los Altos, salir de su tierra para trabajar en otras latitudes ha sido una constante. ${ }^{2}$ Así, desde fines del siglo XIX y durante todo 
el XX se realizaron migraciones estacionales a las fincas cafetaleras del Soconusco y, en las últimas décadas, se comenzó a tomar rumbo hacia diferentes regiones y ciudades, primero dentro del estado de Chiapas y luego fuera de él, hacia estados como Quintana Roo, Yucatán, Campeche, Tabasco, Veracruz y México. ${ }^{3}$ Por esta razón, basta conversar con cualquier hombre o mujer adultos del municipio para encontrar anécdotas sobre diversas experiencias migratorias. Los lugares de atracción han variado a lo largo del tiempo. Hoy, los Estados Unidos de América es uno de los principales destinos y en menos de una década se ha vuelto fundamental en la estrategia económica de gran número de personas.

Dada la novedad de esta situación -evidente en las largas filas de mujeres que reciben remesas en los bancos de la ciudad de San Cristóbal de las Casas-, resulta importante investigar acerca de las características que está tomando la migración internacional en la región y reflexionar sobre los efectos que ha tenido o puede tener en la vida local. En el presente artículo nuestro interés se concentra especialmente en los efectos de la migración respecto a la salud sexual, para lo cual presentamos los resultados del análisis de 16 entrevistas realizadas con hombres y mujeres de habla tsotsil -la mayoría originarios de San Juan Chamula- ${ }^{4}$ quienes han tenido alguna experiencia relacionada con la migración hacia Estados Unidos. Nuestro propósito general es identificar las prácticas de riesgo que tienen lugar durante el proceso migratorio y reflexionar sobre las condiciones estructurales que generan vulnerabilidad en el migrante indígena y en su comunidad frente a las infecciones de transmisión sexual (ITS), particularmente el VIH/SIDA. Éste es un tema que ha sido escasamente explorado en la región y su conocimiento es un asunto de gran importancia para la salud de la población de Los Altos de Chiapas.

El titulo del artículo, además de expresar nuestro objetivo de identificar las condiciones de vulnerabilidad ante el VIH-SIDA entre los migrantes indígenas de Chamula, intenta dar una imagen de la experiencia migratoria que nos relataron los entrevistados. Las barras y las estrellas de la bandera estadounidense representan aquí la condición ambigua del migrante chamula que se ve atraído por un mundo luminoso y prometedor en el sentido económico, pero que se encuentra atrapado en él, no sólo por su condición de ilegalidad, sino por su diferencia cultural que no le permite moverse cómodamente aun en el ámbito latino y lo coloca, como veremos, en condiciones de mayor vulnerabilidad en general, y particularmente ante las infecciones de transmisión sexual.

Para organizar nuestra exposición hemos dividido el texto en cuatro partes. En la primera, Marco de referencia, se expone brevemente los conceptos que guían nuestra reflexión y la manera como se obtuvo la información en campo. En la segunda, Proceso migratorio, aparecen los testimonios de los migrantes respecto al viaje de ida y vuelta a los Estados Unidos con el propósito de conocer los aspectos generales que lo caracterizan. Por ello, aunque se deja entre paréntesis la reflexión acerca del impacto de la migración sobre la salud sexual, se dejan sobre la mesa varios de los elementos que nos ayudarán a realizarla. En la tercera parte, $V$ ulnerabilidad ante el VIH-SIDA, reflexionamos citando los testimonios en que se muestran diferentes contextos, condiciones y situaciones que generan riesgos para la salud sexual. A 
partir de esto, en la parte final, Conclusiones, recapitulamos la información presentada en los apartados anteriores, atamos los cabos sueltos e identificamos diversos aspectos que se entrelazan para generar la vulnerabilidad de los migrantes ante las ITS y el VIH-SIDA.

\section{Marco de referencia}

Para identificar los contextos que colocan a los indígenas de Chamula en condiciones de vulnerabilidad y reconocer las prácticas que los exponen a adquirir infecciones de transmisión sexual, consideramos necesario conocer la manera como se realiza el proceso migratorio, desde la salida de la localidad hasta el regreso a la misma, así como identificar el conocimiento que los involucrados tienen respecto a la salud sexual.

Pero antes, es necesario presentar dos discusiones conceptuales: qué entendemos por proceso migratorio y a qué nos referimos con vulnerabilidad y prácticas de riesgo.

Entendemos la migración como un proceso porque en ella tienen lugar varias etapas o momentos que van desde la decisión de salir del lugar de origen, pasando por las peripecias acaecidas durante el viaje y la adaptación al lugar de destino, hasta el regreso a casa, sea éste temporal o definitivo. La ventaja de analizar procesos migratorios radica en que nos permite tener en cuenta el contexto en el que se genera la migración, al tiempo que nos da elementos para reflexionar sobre los riegos que la acompañan y su impacto en la familia y la comunidad. Además, cuando empleamos el término de migración internacional indígena estamos señalando un proceso en el cual el componente étnico le confiere características diferenciales y la experiencia de los migrantes chamulas es un ejemplo notable al respecto.
Por otro lado, es necesario distinguir los conceptos de riesgo y vulnerabilidad. El primero se refiere a la posibilidad de que un evento considerado adverso suceda (ONUSIDA, 2002; Izazola, 1999) y para el caso de la infección por el VIH, la probabilidad de que una persona pueda contraer el virus. De este modo, el concepto riesgo generalmente evoca a factores del individuo y su conducta y los términos prácticas de riesgo, comportamientos de riesgo o factores de riesgo suelen emplearse en ese sentido.

El concepto de vulnerabilidad, por su parte, pretende brindar una comprensión más amplia de los fenómenos estructurales condicionantes del riesgo y no sólo de aquellos referidos a la esfera individual (Delor y Hubert, 2003:1; Bronfman, et. al, 2005; Izazola, et. al.:1999:38). Ser vulnerable en el contexto de VIH/SIDA significa tener poco o ningún control sobre el riesgo de adquirir la infección, lo que implica que la vulnerabilidad es el resultado de la interacción de diversos factores, tanto individuales (incluyendo los aspectos biológicos) como sociales, culturales, demográficos, legales, económicos y políticos. ${ }^{5}$

Así pues, nuestro marco de análisis tiene como eje tres conceptos: proceso migratorio, que presenta el fenómeno migratorio mostrando las condiciones que lo propician y las diversas prácticas y condiciones de peligro que lo acompañan; prácticas de riesgo, que nos sirve para referir los riegos en que incurren los individuos y vulnerabilidad, que nos es útil para señalar las condiciones y situaciones que se combinan para generar tales acciones riesgosas y enfatizar que detrás de las prácticas de riesgo individuales existen diversos factores -culturales, sociales y económicos- que las propician. 
Con estos conceptos, nuestro objetivo es presentar diversos testimonios sobre la experiencia migratoria de los chamulas y reflexionar sobre su impacto en la salud sexual. Fue parte de nuestra estrategia indagar acerca del conocimiento de los entrevistados respecto a las infecciones de transmisión sexual, los síntomas que las acompañan y su prevención. Sin embargo, es necesario aclarar que el conocimiento sobre salud sexual lo valoramos exclusivamente en términos de lo que la medicina moderna (científica) considera válido en la actualidad, por lo cual asumimos juicios que pueden cambiar en un momento dado y cuyas implicaciones constituyen un campo de análisis y reflexión que aquí no abordaremos.

Por otra parte, los conceptos que elegimos no agotan las posibilidades de reflexión e interpretación de los testimonios que se presentan. Nos limitamos a dar un marco general para ordenar la información etnográfica, la cual consideramos de enorme riqueza e utilidad no sólo en lo relativo a la salud sexual, sino para todos aquellos interesados en las características que está tomando la migración internacional en la región. Por ello, aunque no nos hemos propuesto contribuir a la compresión teórica de la migración, consideramos que la información presentada puede ser aprovechada por todos los interesados en profundizar sobre el fenómeno.

Así pues, en la mayor parte del artículo nos centramos en los testimonios recabados citando de manera abundante la voz de las 16 personas que entrevistamos en los meses de marzo y abril de 2005. Once de las entrevistas fueron hechas a personas con experiencia migratoria internacional (siete a hombres y cuatro a mujeres) ${ }^{6}$ y las cinco restantes se realizaron a mujeres que se quedaron en la comunidad mientras el marido emigró. ${ }^{7}$ En todos los casos se buscó establecer una conversación abierta, aunque basándonos en un guión de preguntas cuyas respuestas pretendíamos conocer. De este modo, discurrimos siguiendo el hilo de la conversación, pero guiando la misma hacia los temas que nos interesaban.

Debido a que la sexualidad es un tema delicado, se procedió con tacto y respeto para lograr la participación de las personas; se les explicó con anticipación de qué se trataba la entrevista y que la información sería con fines de la investigación, y que se mantendría el anonimato de las personas. Dado que en casi todos los casos los entrevistados prefirieron hablar en su lengua materna, las entrevistas, en su mayoría, fueron realizadas en tsotsil. ${ }^{8}$ Sé indagó sobre los motivos de la migración, el viaje, la vida y el trabajo en el lugar de destino, así como las situaciones que involucraban posibles prácticas de riesgo relacionadas con la sexualidad y el conocimiento sobre ITS y VIH/SIDA.

\section{El proceso migratorio}

Para exponer las características y situaciones que rodean el viaje y el regreso a la comunidad hemos dividido nuestra presentación en cuatro partes: primero nos referimos al contexto en el cual surge el deseo de migrar, seguimos con una revisión del trayecto durante el viaje de ida, nos detenemos para observar la manera de vivir en el país norteño y finalmente describimos el contacto de los migrantes con la comunidad y su regreso a ésta. Al hacerlo, ponemos en la mesa la información necesaria para reflexionar sobre la vulnerabilidad de los migrantes ante las ITS y el VIH-SIDA. 
El contexto local: condiciones y motivos para la migración internacional

Chamula tiene una extensión territorial de $82 \mathrm{~km}^{2}$ y una población de 67085 habitantes (INEGI, 2005) ${ }^{9}$ situación que lo convierte en uno de los municipios con mayor densidad demográfica en Los Altos. En esta región, el constante incremento poblacional, -que comenzó a ser problemático desde 1940- ha creado gran presión sobre la tierra, razón por la cual, las parcelas familiares, mediante la herencia, se han reducido generación con generación y los suelos han ido en constante deterioro (Viqueira, 2002b: 224). Esto ha provocado que las condiciones de vida en el municipio, desde el ámbito económico, sean cada vez menos sustentables. Desde hace décadas, la migración ha sido una opción permanente para mitigar la pobreza y mejorar económicamente. Sin embargo, hoy el desplazamiento dentro del país no retribuye lo suficiente. Ante ello, ha tomado auge el éxodo internacional hacia los Estados Unidos de América. ${ }^{10}$

Acorde con este panorama los entrevistados, al preguntarles por qué decidieron migrar a los Estados Unidos, respondieron que deseaban mejorar económicamente. El principal argumento citado es, precisamente, la baja productividad en el campo y la necesidad de pagar las deudas, muchas de ellas contraídas, precisamente, para costear las labores agrícolas.

- ¿Porqué decidiste ir al norte?

- Se gana mejor, en cambio acá trabajas y no sale nada. A veces a las milpas les pegan plagas, el maíz sale muy podrido y no lo puedo vender bien. El fertilizante que le doy siempre me sale muy caro, hasta me llené de deudas.

(Hombre con experiencia migratoria, 45 años, Las Ollas, Chamula.)
De igual forma, un hombre que migraba estacionalmente a la zona cálida del estado y había logrado comprar un terreno para sembrar allá, señala que la migración dentro del estado ya no es rentable. Él tuvo que deshacerse de su patrimonio cuando las deudas comenzaron a sofocarlo:

- ¿Todavía tienes o ya no tienes propiedad [en tierra caliente]?

- No, ya no, vendí.

- ¿Por qué vendiste?

- Porque no resulta, no da suficiente. Por ejemplo, yo compraba el líquido, el fertilizante, pagando interés, yo pagaba interés al 10\% y cuando sacaba la cosecha no me daba.

- ¿No alcanzabas a pagar la deuda?

- No alcanzó para pagar la deuda y así lo deje, y vine aquí [la localidad de Las Ollas Chamula], y cómo no tenía casa, me fui al otro lado [Estados Unidos] [...] Cuándo me fui ya debía ya 4000 ó 5000 pesos y mi casa estaba a punto de caer, entonces quería pagar y hacer mi casa.

(Hombre con experiencia migratoria, 33 años, Las Ollas, Chamula.)

Combinado con el apremio debido a la situación económica, está también el deseo de obtener algunos bienes que son signos de prosperidad y status dentro de la comunidad. Las ambiciones más comunes son el comprar un carro y construir una casa "de colado" (es decir con paredes de bloques y techo de concreto). Varios entrevistados expusieron así su motivo:

- Mi casa era muy pobre, por eso tuve que ir, para tener mi casa y pagar la deuda que tenía [...] según yo me iba comprar mi carro y mi casa, 
pero no pude comprar mi carro, lo único que pude hacer fue mi casa.

(Hombre con experiencia migratoria, 45 años, Las Ollas, Chamula.)

Para los más jóvenes estas ambiciones están ligadas al deseo de encontrar una esposa y formar una familia. Sin embargo, es probable que después de conseguirlo pensarán en volver a migrar, pues el dinero dura poco y generalmente no se invierte en algún negocio productivo. El siguiente testimonio es de un joven que regresó para encontrar una esposa y contraer matrimonio. El comentario del entrevistado presagia un nuevo viaje tal como ha pasado con otros jóvenes que después de casarse y engendrar un hijo vuelven a irse:

- si no hubiera yo ido, no tuviera mi casa, no sé dónde estaría viviendo con mi esposa [...] estuviera con mi papá o con mi suegro, no sé. Si no hubiera ido al norte, te digo, es la única diferencia que veo, la alimentación casi es igual, por ejemplo en la forma de vestirme, veo que es lo mismo, lo único diferente es mi casa.

(Hombre con experiencia migratoria, 26 años. Las Ollas, Chamula.)

En muchos casos, varios miembros de una familia deciden irse de manera colectiva para solucionar sus problemas. La siguiente mujer opina sobre la penuria material de su familia antes de que ella, su hermana menor y su padre decidieran ir juntos a los Estados Unidos:

- estaba muy pequeña mi casa hasta con trabajo nos dábamos vuelta [...] estaba muy chiquita, por eso pensamos irnos con mi papá y porque debíamos un poco, por eso.
(Mujer con experiencia migratoria 20 años, Las Ollas, Chamula.)

Algunos entrevistados, además, contrastan el poder adquisitivo y el nivel de vida en los Estados Unidos, con las condiciones materiales en la localidad de origen. Las ventajas de migrar les resultan evidentes:

$-[\ldots]$ allá aunque saqué sólo cuarenta dólares a la semana, pero ya como mejor, en cambio acá sacamos cuarenta o cincuenta pesos y con dos 'Pepsi jumbo' que compre yo, ahí ya se me acabó todo el dinero. En cambio allá un 'jumbo' sale como a peso o uno cincuenta [dólares], no que acá me mato a trabajar más de ocho horas y no saco nada, en cambio allá si saca uno bien.

(Hombre con experiencia migratoria, 45 años, Las Ollas, Chamula.)

Ante este panorama en la economía local, la posibilidad de migrar resplandece en el ambiente: casas nuevas de colado, familias que reciben remesas de sus familiares que están en el norte, los recién llegados que pasean en sus camionetas, las salidas que se organizan cada mes... La migración está en la mente y el paisaje de los chamulas. Aunque para partir primero deben conseguir el dinero y tener redes sociales y condiciones económicas que los avalen. ${ }^{11}$

\section{El viaje y la pasada}

Durante nuestro trabajo de campo en la localidad de Las Ollas, donde realizamos la mayor parte de las entrevistas, tuvimos conocimiento de varias personas que se dedican a transportar migrantes a Estados Unidos, entre ellas el esposo de una mujer que logramos entrevistar de modo 
informal. Cuando platicábamos con ella nos llamó la atención que dijo que su esposo regresa "del norte" cada mes. Después comprendimos que el hombre se dedica a trasladar migrantes a la frontera. Nos comentó que el costo del viaje es de veinte mil pesos, los cuales, como corroboramos con otros testimonios, en ocasiones son dados a crédito por el mismo "pollero", como se llama comúnmente a las personas que se dedican a este negocio. Así lo comenta la siguiente entrevistada:

-[...] el guía estaba a punto de irse y me dijo, 'si quieres ir conmigo, ve a buscar dinero', yo le dije, 'pues no, no encuentro el dinero', entonces me dijo, 'si quieres te voy a prestar, y cuando llegues, para que nos vayamos juntos, me vas a pagar', me dijo. 'Está bien', le dije, 'esta bien, entonces sí voy con usted'.

(Mujer con experiencia migratoria, 25 años, Las Ollas, Chamula.)

Para pagar la deuda contraída al iniciar el viaje, el migrante debe sacrificar parte del primer año de trabajo. Después podrá mandar remesas mensuales que van de dos mil hasta diez mil pesos mexicanos, según sea su salario y la oferta de trabajo. Algunos sólo logran empleos de dos o tres días a la semana, con períodos en que no se solicitan sus servicios. Otros logran acomodarse mejor y los más afortunados consiguen dos empleos distintos. El salario promedio en un trabajo estable es de doscientos cincuenta dólares por semana, lo que equivale a dos mil quinientos pesos mexicanos aproximadamente.

El propósito principal al indagar acerca del itinerario para llegar a la frontera y cruzarla fue reconocer los factores que colocan al migrante en condiciones de vulnerabilidad para adquirir una infección de transmisión sexual. De esta manera, en la guía de entrevista pusimos énfasis especial en determinar la forma del viaje y las actividades que se realizan durante las estaciones o paradas.

En torno a esto, las repuestas de los entrevistados refieren en general que el viaje se efectúa precavidamente, sin que existan muchos contratiempos ni oportunidades para distracciones. Así, en la ciudad fronteriza de Altar, Sonora -donde los migrantes en ocasiones tienen que esperar un tiempo antes de que sea oportuno cruzar la frontera- las personas manifestaron guardar todas las precauciones posibles. El propio pollero los instruye al respecto pues se considera que el lugar está plagado de delincuentes que acechan migrantes incautos:

- ¿Que hacían en Altar, Sonora?

- Nada, allí estábamos encerrados todos porque no podíamos salir porque allá hay muchos rateros, por eso el guía que nos llevó quiere que no andemos en la calle porque que tal que nos perdemos, él ya no va a ser responsable si andamos en la calle.

— ¡Ah!, ¿así es?

- Sí, él se encargaba de todo, nos daba de comer.

- ¿Y cómo está eso? ¿En un solo cuarto estaban juntos hombres y mujeres?

- No, cómo crees, estamos separados, de hecho en un solo hotel pero estamos separados.

(Mujer con experiencia migratoria, 20 años, Las Ollas, Chamula.)

De esta manera, encontramos que la estrategia para ir al norte está cuidadosamente planeada y que - por lo menos en los testimonios registrados- las personas hacen todo lo posible para evitar cualquier problema. La ruta está 
definida con claridad. Se toma primero un autobús hacia la ciudad de México. Ahí de inmediato se aborda otro con rumbo a la ciudad fronteriza de Altar, Sonora. Al llegar, sólo se espera el momento adecuado para cruzar la frontera y caminar por el desierto, por lo regular, durante tres días y tres noches.

Enfrentadas las penurias del desierto, en el otro lado, el mayor peligro ha pasado y sólo queda moverse a lugares donde habitan paisanos tsotsiles. Por eso, más allá del cansancio, las lesiones, la falta de agua y comida o la amenaza de morir o ser deportados, los migrantes no refirieron situaciones durante el viaje que pudieran representar un riesgo específico para su salud sexual. Al parecer la tensión del viaje es demasiado fuerte como para que durante éste las personas incurran en comportamientos sexuales relajados que los expongan a las infecciones. El desierto y la condición de ilegalidad son los obstáculos reales que deben ser sorteados. En este sentido, las experiencias narradas, aunque son contadas con gran naturalidad, son verdaderamente extremas:

- ¿Tuviste problemas durante el camino... te enfermaste, se te acabo el dinero?

- No, no, lo único que me pasó es que me salieron ampollas en mis pies [...] sufrimos hambre y sed $[\ldots]$ lo bueno es que encontramos un pozo [...] estaba muy sucio pero como nos estábamos muriendo de sed tuvimos que tomar.

(Hombre con experiencia migratoria, 45 años, Las Ollas, Chamula.)

- Lo único que me pasó fue que al caminar, de noche caminando, un día no me acuerdo, me empezó un calambre en mis piernas.

- ¿Y quién te curó ese día para que pudieras seguir caminando?

- El guía, me sobó con el alcohol para calentarme para poder seguir caminando.

- ¿Y cuánto tiempo entonces tuviste que caminar?

- No caminamos mucho, caminamos dos días y dos noches.

(Hombre con experiencia migratoria, 43 años, Las Ollas, Chamula.)

Vida cotidiana de hombres y mujeres en "el norte"

En Estados Unidos, los migrantes por lo general procuran establecerse en lugares donde habitan paisanos chamulas. ${ }^{12}$ Los hombres, si viajaron sin pareja o familiares, se unen con otros para rentar un departamento o una casa trailer. Por lo regular, no es posible establecerse más de cinco en un mismo lugar (el arrendatario no lo permite), pero el caso siguiente fue diferente:

- ¿Cuando llegaste al norte con quién te fuiste a vivir? Me decías que no tenías ni un familiar.

- Con esos compañeros que te digo, unos tenían amigos allá y otros ya tienen familia.

- ¿Son puros paisanos tuyos o hay otras gentes que son mestizos?

- Sí hay [mestizos] pero en otro barrio [...]

- ¿Y cuántas personas vivían en tu departamento?

- Vivíamos diez.

- ¿Los diez eran paisanos?

- Sí, te digo que fuimos juntos.

- De los diez con quienes vivías, chabía mujeres?

- No, son puros hombres.

- ¿Y de esos diez, eran solteros o casados?

- Algunos son solteros y otros son casados.

(Hombre con experiencia migratoria, 27 años, Las Ollas, Chamula.) 
Las mujeres migrantes, cuyo número es inferior al de migrantes hombres, ${ }^{13}$ por lo regular llegan a vivir con familiares cercanos. En el caso de las parejas (sea porque migraron juntos o cuando se juntaron allá), lo común es que decidan rentar un lugar aparte y compartirlo con una o dos parejas más:

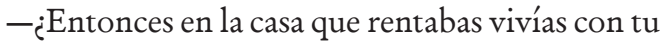
pareja, con tu esposo que dices?

-Ah, de mi esposo, no, ya cuando me junté con mi esposo que te digo, ya nos separamos con mi papá. Mi papá quedó con mi hermanita y sus amigas de mi hermanita. Nosotros salimos a rentar ahí, enfrente nada más.

(Mujer con experiencia migratoria, 20 años, Las Ollas, Chamula.)

Luego de la llegada, generalmente se tienen que esperar algunas semanas antes de poder encontrar un trabajo. Durante este lapso los migrantes nuevos son apoyados por sus "paisanos" (generalmente otros tsotsiles de Chamula) que ya están establecidos y trabajando:

- ¿Entonces, cuánto tiempo tardaste en encontrar trabajo?

- ¡Eh, tardé como un mes!

- ¿Y donde conseguías dinero o quién te daba de comer mientras que conseguías trabajo?

- Ah, tuve que pedir prestado mientras que conseguía trabajo.

- ¿Con quién si no tenías familiares?

- Ah, como no tenía trabajo, pedí prestado a los que ya están trabajando ahí [...] allá la mayoría habla inglés y yo que con trabajo hablo español, por eso mismo no encontraba rápido trabajo, peor cuando fui, éramos muchos [...] algunos llegan directamente con familiares que tienen allá y ya están trabajando y otros compañeros que fuimos con ellos aquí en la misma localidad, casi no conocen nada, igual como yo. Pero algunos que tenían familiares llegaron con trabajo.

(Hombre con experiencia migratoria, 43 años, Las Ollas, Chamula.)

Una vez establecidos y con trabajo, la vida de los migrantes, según la mayoría de las referencias, transcurre en tres espacios. Los departamentos o trailers en que se hospedan, el lugar de trabajo y la tienda de autoservicio donde se compra la comida de la semana. En casa, las labores domésticas como el aseo y la cocina corresponden a la mujer. Sin embargo, dado que la población femenina es escasa, los hombres sin pareja se ven obligados a realizar tareas que en la localidad normalmente realizan las mujeres:

- Entonces, ¿en el barrio donde quedaste hay lugares donde comprabas comida o hacían comida?

- Sí lo hacíamos, porque si comprábamos nos sale muy caro, de hecho hay restaurantes pero no es igual que lo preparemos.

- ¿Ah entonces sólo compran la despensa para cocinar?

- Sí, preparamos.

- ¿Y con quiénes preparan la comida?

- Con unos compañeros de la renta que estamos viviendo en un solo departamento.

- ¿Ah, y cuántos son los que cocinan?

- De dos o tres personas [...]

- ¿Y nunca tuviste problema con tus compañeros de cuarto, por cualquier cosa, de aseo, todo?

- Pues a veces, pero casi no, a veces nomás nos decimos que tenemos que hacer el aseo para bien de nosotros, te imaginas que usas los trastes y los dejaras todos, eso a mí tampoco me gusta, pero

\section{7}


por eso nos decimos que cada quien que cocina o cuando cocinamos todos que limpiemos lo que usamos.

(Hombre con experiencia migratoria, 45 años, Las Ollas, Chamula.)

Los fines de semana, sábado y domingo, que por lo regular son los días en que no se asiste al trabajo, las personas aprovechan para ir a las grandes tiendas de autoservicio a surtir su despensa para la semana. Por lo general se va en grupo, de manera que las compras constituyen también un momento de distracción y socialización con otros compañeros migrantes:

- Cuando no trabajábamos salíamos a comprar en una tienda grande, ahí iban personas de otros lugares, pero iban más mexicanos, iban a comprar. Ahí nos encontrábamos los compañeros del trabajo.

(Hombre con experiencia migratoria, 45 años, Las Ollas, Chamula.)

- ¿Allá en el norte salías a pasear con tus paisanos y compañeros de trabajo?

-No sólo vamos a otros barrios para comprar nada más, pero no salíamos a pasear, nada más cada fin de semana salíamos a comprar [...] se llama WalMart, se parece a "El mayoreo" que hay en San Cristóbal, así se llama la tienda.

(Mujer con experiencia migratoria, 20 años, Las Ollas, Chamula.)

Según se aprecia en los testimonios, los migrantes chamulas no tienen muchas oportunidades de conocer otros ámbitos del país en que trabajan. Todos coincidieron en que su condición de ilegales los obliga a permanecer en sus casas y se arriesgan poco a conocer más espacios del país vecino:
- ¿Y usted no fue a lugares a donde, por ejemplo, venden alcohol, por ejemplo un bar o algún restaurante?

- Quizás algunos salían [se refiere a compañeros mestizos], pero yo casi no salía porque no conozco y porque no podemos andar mucho en la calle porque nos puede agarrar la migración y te imaginas, nos sale peor.

(Hombre con experiencia migratoria, 45 años, Las Ollas, Chamula.)

- ¿Entonces, no trabajabas todos los días?

- No, sólo dos o tres días a la semana.

- ¿Y qué hacías los otros días?

- Nada, ahí me quedo donde rento, por lo mismo que no tenía dinero, no salía, para salir se necesita mucho dinero [...] de vez en cuando salía a comprar lo que consumimos a la semana, pero no tomar trago [bebidas alcohólicas], porque allá en el barrio donde vivimos, no hay bares cerca ni cantinas. Nada más hasta el centro pero yo no llego hasta allá.

(Hombre con experiencia migratoria, 25 años, Las Ollas, Chamula.)

Sólo un migrante que vivió y trabajó en la ciudad de Atlanta, en un contexto en que la mayoría de sus compañeros eran mestizos, mencionó haber paseado en parques de atracciones y alguna vez haber asistido a bailes de música popular mexicana. Respecto a esto último comentó:

- ¿Y alguna vez estuviste en bares o cantinas, lugares en que había mujeres y bebida?

- Sí, en una cantina.

- ¿Y cómo era el ambiente de ahí?

- Pues, bueno, yo lo veía diferente, diferente de aquí, había música, taba lleno [...] Los famosos 
En contraste, en Estados Unidos, hombres y mujeres

ahí llegan como los Tigres o los Temerarios.

(Hombre con experiencia migratoria, 33 años, Las Ollas, Chamula.)

A partir de lo anterior, podemos señalar que junto al mundo latino-mestizo de la migración ilegal en Estados Unidos, ahora existen grupos indígenas que se mantienen en cierta medida segregados de ese ámbito simbólico. ${ }^{14}$ Sin embargo, aunque los testimonios muestran en general a un migrante indígena que permanece aislado y temeroso del nuevo entorno, de este lado podemos observar que rápidamente se han tomado elementos de la "cultura migrante" y ahora la música de narcocorridos y el estilo "norteño" o "cholo" son una moda en el municipio.

Pero aunquelos migrantes chamulas regularmente no establecen lazos importantes con otros grupos de migrantes, la nueva situación en que viven propicia adaptaciones en algunas pautas culturales. Esto es evidente en la forma como se establecen las relaciones de pareja. Los nuevos espacios de movimiento y la participación creciente de las mujeres en la migración están generando prácticas de cortejo que se alejan de las formas tradicionales. Una mujer que tiene su marido en Estados Unidos nos relató la experiencia de cómo se unió con su esposo:

-¡Ay, no sé dónde me conoció él! De repente [...] me llamaron en la agencia, porque mi esposo le había hablado al agente municipal de la localidad, ya cuando me llamaron, me llamaron y le llamaron a mi familia que se llegaran ahí, y me dijeron que si me quería casar con su hijo. Nunca me habló, nada más así que fue que me atraparon en su casa, que nunca nos hablamos antes de juntarnos. De repente llegaron así. (Mujer con esposo migrante, 22 años, Las Ollas, Chamula.) se socializan y se conocen principalmente en el trabajo durante los brakes (pausas para ir a comer) y en la tienda Wal Mart. Las mujeres, que como mencionamos son menos que los hombres, reciben muchas invitaciones para vivir juntos. Dos de ellas comentaron que conocieron y platicaron con sus parejas en el trabajo. Sin embargo, ambas señalan que no hubo noviazgo, sino que se pasó de una amistad informal directamente a la vida conyugal:

- ¿Tus mejores amigos de donde eran?

-De Oaxaca, de Veracruz, de Tapachula.

- ¿Cómo se llevaban, dónde platicaban, salían a tomar algún refresco?

- Sólo cada brake" [...]

- ¿Pensabas que ibas a encontrar marido en el norte, habías imaginado?

- No, eso sí que no.

- ¿Tú pensabas ir y volver soltera?

- Sí, pero hay mucha gente, pues.

(Mujer con experiencia migratoria, 18 años, Las Ollas, Chamula.)

- Mi esposo allá lo encontré en el norte, allá lo conocí, en el trabajo lo conocí, ahí nos hablamos, ahí lo encontré.

- ¿Y de dónde es tu esposo?

- Es de Cruztón [una localidad de Chamula vecina de Las Ollas]

- Ah, es tu paisano.

- Sí es mi paisano [...]

- ¿Entonces, cuánto tiempo duraron juntos de novios y todo?

- Bueno, cuando estuve con él fue un año pero no fuimos novios, sólo nos conocimos, hablamos en el trabajo y de ahí nos juntamos [...]

$-¿ Y$ cuando estabas soltera tuviste enamorados o qué? 
- Sí, me querían muchos hombres, pero te digo, no quería aceptar, yo quería regresar sola, pero desgraciadamente lo conocí a él y acepté.

- ¿Y de dónde eran tus enamorados?

- Bueno, unos eran mis paisanos y otros eran de otros lugares, algunos incluso eran mestizos también.

(Mujer con experiencia migratoria, 20 años, Las Ollas, Chamula.)

A pesar de lo anterior, es necesario apuntar que las nuevas pautas de cortejo en vez de garantizar mayor equidad de género, colocan a las mujeres en condiciones de gran inseguridad en relación con la vida familiar, pues en el nuevo ambiente, como veremos adelante, la promiscuidad varonil se convierte en la norma y los lazos de pareja son rotos con facilidad.

Contacto con el lugar de origen y regreso a casa

En general, los migrantes mantienen contacto telefónico frecuente con su familia. Por lo menos hacen una llamada al mes, aunque la mayoría se comunican cada ocho o quince días, e incluso, tuvimos noticia de varias personas cuyos familiares se comunican diario. La mayoría de los migrantes envían remesas mes con mes, y sólo cuando hay poco trabajo retrasan su envío un par de meses. ${ }^{15}$

De esta manera, aunque nos enteramos de casos en que el hombre migrante encuentra una nueva mujer y desampara a la familia que tiene en la localidad de origen, es claro que a pesar de estar tan lejos, para la mayoría de los chamulas, su municipio sigue siendo el centro donde gravita su identidad y donde colocan sus aspiraciones de mejoramiento económico. "El norte" sólo es un lugar de paso y la mayor parte del dinero que ganan se destina a sus parientes en México.
Un caso que ilustra de manera particular la fuerza de la comunidad es el de un señor que se fue porque le asignaron con anticipación un cargo comunal y consideró necesario ir antes al "norte" para no pasar por apuros económicos. Los cargos son absorbentes y generalmente implican una carga económica para el elegido, quien tiene poco tiempo para trabajar en su propio beneficio:

- ¿Tú sabías qué cargo te iban a dejar después que te fueras al norte?

- Sí lo sabía, por eso me fui a trabajar al norte antes que prestara mi servicio como comité de educación.

- ¿Cómo supiste que te iban a dejar de comité de educación?

- Antes que me fuera al norte, estuvimos en una reunión de asamblea, ahí me eligieron los habitantes de esta localidad.

(Hombre con experiencia migratoria, 45 años, Las Ollas, Chamula.)

Por otro lado, según los testimonios obtenidos, en el viaje de regreso no existe ningún riesgo notable y las personas toman las precauciones necesarias para no correrlo. La mayoría regresa en autobús y algunos toman un vuelo que los deje en el aeropuerto de Tuxtla Gutiérrez. Por lo regular, la estancia en los Estados Unidos se prolonga entre dos o tres años. La mayoría regresa con la intención de quedarse, sin embargo, en varios casos después de un tiempo en la comunidad, los retornados toman la decisión de volver a migrar, con lo que se inicia un nuevo ciclo:

- ¿Por qué razón se fue tu esposo hasta el norte?

$-[. .$.$] ya es la segunda vez que se fue, la primera$ trajo dinero y se lo prestó a su hermano y le 
fue pagando de mil a dos mil pesos y nunca vimos en qué se fue el dinero. Mi esposo se le ocurrió comprar un carro y el carro le salió en sesenta y cinco mil, como lo había prestado con el hermano el otro dinero que tenía, tuvo que pedir prestado veinte mil mi esposo para poder pagar el carro. Y de los veinte mil que le prestaron a mi esposo, tuvo que pagar el diez por ciento de interés, por eso mismo se tuvo que ir al norte para pagar todas las deudas que tenía, eran como cuarenta y cinco mil con todo e interés.

(Mujer esposa de migrante, 27 años, Las Ollas, Chamula.)

De esta manera, migrar comienza a convertirse en un evento periódico, que se repite a partir de endeudamientos o porque se agotan los recursos que se habían conseguido. Al mismo tiempo, cada nuevo viaje brinda la oportunidad para que un nuevo familiar o amigo emprenda la aventura y se enrole en el viaje, aumentando cada vez el flujo de migrantes.

- ¿Ahora tienes un familiar en el norte?

- Sí, sí está mi hijo, está él.

- ¿Y a él quién le invitó a ir o usted lo convenció que se vaya, usted lo invitó?

- Sí, sí, cuando estuve ahí, yo le dije que se fuera, porque hay un buen trabajo.

(Hombre con experiencia migratoria, 45 años, Las Ollas, Chamula.)

En general, podemos observar que el dinero fluye del norte aumentando la prosperidad material de las familias. Hay nuevas casas, nuevos coches, más aparatos eléctricos, aunque lamentablemente, esto no indica necesariamente mejoría de las condiciones de salud.

\section{Vulnerabilidad ante el VIH-SIDA}

Una vez que hemos conocido un poco la manera como se realiza el proceso migratorio hacia los Estados Unidos de Norteamérica, analizaremos la información relacionada con las condiciones y prácticas que ponen a los migrantes en peligro de adquirir enfermedades de transmisión sexual como el VIH-SIDA. Comenzaremos hablando del consumo de alcohol y de comercio sexual como prácticas de riesgo cotidianas, para después analizarlo con relación a los roles y relaciones de género que se presentan tanto en Estados Unidos como en Chamula. Al mismo tiempo, apuntamos la manera como se conjugan elementos culturales y materiales para generar una situación de vulnerabilidad ante enfermedades como el VIH-SIDA. Dada la carga moral que existe alrededor de la sexualidad, algunos pasajes de los textos pueden parecer juicios sobre la conducta de los migrantes. Es necesario aclarar que esa no es la intención y reafirmar que lo que nos interesa es encontrar las condiciones, conocimientos, actitudes, valores y prácticas que generan vulnerabilidad ante el contagio según los parámetros que la medicina moderna considera válidos en este momento.

\section{Consumo de alcohol y sexo comercial}

Todos los migrantes entrevistados, tanto mujeres como hombres, señalan el consumo de alcohol y de sexo comercial como práctica generalizada entre la población masculina. Los hombres suelen comprar, los fines de semana, cerveza que, para mayor tranquilidad, beben en los departamentos en que se hospedan: 
- ¿En el barrio donde viviste hay bares cerca donde te puedas divertir?

- Los hay, pero yo como te digo nunca tomé. De hecho, tomar trago no se puede, cuando quieres tomar, o algunas personas que quieran tomar, pueden tomar en su cuarto pero menos en el bar, porque en el bar sale muy caro. Por otro lado, si te agarra la migración te vas al bote y te imaginas, no podemos pagar la deuda y todavía vamos a la cárcel, pues no es el caso.

(Hombre con experiencia migratoria, 45 años, Las Ollas, Chamula.)

Al mismo tiempo, una red de comercio sexual a domicilio destinada a atender a la población migrante toca a la puerta. Así describe esta práctica una mujer con experiencia migratoria:

- Sí, beben los fines de semana, se juntan. Digamos que viven muchos hombres en un apartamento y se juntan, beben, y ahí llegan las sexoservidoras.

- ¿Cómo visten?

- ¿Cómo visten?... mejor, con sus faldas, así con short, para que no sospeche nada la policía, porque cuando les cacha la policía luego se van a la cárcel o en una corte. Sí, pero, ellas se van en bici.

- ¿En bicicleta?

- Sí, como si fuera un atlético.

- ¡Ah!, atleta.

- Sí, así se ve.

- ¿Y ellas llegan a los departamentos de los hombres?

- Sí, a tocar. O sino va un hombre, este, así, digamos a ofrecer... Sale un hombre del carro, toca la puerta a ver si quieren mujer, y ahí llega la mujer en el carro.

(Mujer con experiencia migratoria y esposo migrante, 24 años).
De esta manera, para la gran mayoría de los hombres, el consumo de sexo comercial se torna habitual:

- Allá en el norte no sabes si hay mujeres, o sea que viven cerca de donde vives $u$ hombres que llegan con las mujeres o mujeres que vienen con los hombres a que las compren?

- Sí hay, cómo no, la mayoría lo hacen así.

(Hombre con experiencia migratoria, 26 años, Las Ollas, Chamula.)

- ¿Cuánto cobraban?

- Veinte o veinticinco dólares [...]

- ¿Y más o menos como cuántas veces tuviste relaciones con una de estas mujeres?

- No, pues no llevaba la cuenta.

(Hombre con experiencia migratoria, 33 años, Las Ollas, Chamula.)

Como se observa, el sexo a domicilio está a la orden del día. Una manera de solicitarlo es por vía telefónica. Sin embargo, como corroboró la mayoría de los entrevistados, las más de las veces el sexo servicio se ofrece directamente en los barrios de los migrantes. En estas circunstancias hay espacio para la práctica del regateo, el testimonio del siguiente migrante casado lo ilustra claramente:

- ...tocan la puerta, '¿cuánto?', dicen, 'treinta dólares', 'no tengo, tengo nomás veinte dólares', 'bueno, échalo pues tu palito', y así.

(Hombre con experiencia migratoria, 29 años, Originario de Nichnamtik, Chamula.)

Hay que señalar, además, que este tipo de prostitución es la menos cotizada en los Estados Unidos. Según el testimonio informal de un 
migrante mestizo originario de Michoacán que ha vivido en Atlanta, estas redes de comercio sexual son manejadas por latinos y atienden a la población migrante de más escasos recursos, incluidos los indígenas mexicanos y guatemaltecos. ${ }^{16}$ El mote popular con el que se conoce a dichas sexoservidoras es el de "treinteras" precisamente por el precio de su trabajo, aunque, como hemos visto, pueden cobrar mucho menos sobre todo cuando han perdido la juventud. El mismo entrevistado explica:

-...llegaban a la casa, así como que más limpio.

[...] Sí, llegan a la casa, tocan. Pero también hay mujeres que sí están sanas, pero también hay mujeres así como en La Merced [se refiere al DF, donde fue migrante años atrás], pero así no le entro, tampoco no le entro [...]

- ¿Y allá cuánto cobran?

- Bueno, allá hay de treinta dólares, de veinticinco dólares, de veinte dólares. Según de la calidad de la muchacha que venga: si es jovencita, pues más caro.

(Hombre con experiencia migratoria, 29 años, Originario de Nichnamtik, Chamula.)

El contraste hecho entre la prostitución en Estados Unidos y un barrio del Distrito Federal, en la Ciudad de México, muestra uno de los prejuicios que genera más riesgo de contraer infecciones de transmisión sexual, pues el entrevistado considera la limpieza y la buena apariencia de las mujeres como sinónimo de sanidad. En este sentido, el entrevistado comenta que de igual manera cuando las mujeres acceden a su petición de tener sexo sin condón, primero le inspeccionan el pene en busca de evidencia de enfermedad:
-Y cómo lo ven?

- Pues lo checan, lo checan. Lo agarran y todo. Y también uno mismo, tienes que abrirla la mujer, checarla si está sana o algo enferma, o si está medio enferma mejor no [...] De... de... de otro tipo de enfermedades no se ve, pero así de gonorrea, de otra cosa, se ve rápido, se ve rápido, porque también yo tengo experiencia de eso de verlo.

(Hombre con experiencia migratoria, 29 años, Originario de Nichnamtik, Chamula.)

Así pues, las "treinteras" visitan semanalmente los barrios de migrantes y muchas veces una sola mujer atiende a todos los hombres que se encuentren tomando licor en algún departamento. En tales circunstancias, aunque son estrictamente vigiladas por la persona que las traslada, dentro del departamento pueden negociar para obtener dinero extra, incurriendo algunas en prácticas de riesgo como el sexo sin condón. Así lo muestran los siguientes testimonios:

-...y pasan todos los hombres... todos. Y yo a veces los veo cuando vivía ahí, entra uno, sale otro, entra uno, sale otro... y ya después sale la mujer llena de billetes.

(Mujer con experiencia migratoria y esposo migrante, 24 años, originaria de Teopisca).

- Y cuando estaba usted con estas muchachas [trabajadoras de sexo comercial], ¿ellas traían condón?

- ¡Ah, sí! Ellas tienen condón. Nos daban condón, pero yo lo quería que no, porque condón no me gusta, no se siente igual. Yo pagaba más... yo pagaba más, yo le daba más dinero para que se dejara conmigo así sin condón.

\section{3}


- ¿Y qué decía la muchacha?

- Ta' bien, ta' bien... hasta me decía 'papito'. (Hombre con experiencia migratoria, 29 años, Originario de Nichnamtik, Chamula.)

Es razonable discutir si este tipo de negociaciones son eventos aislados o si son frecuentes, sin embargo, el solo hecho de que sucedan ya es un indicio, pues la misma frecuencia con que se solicita el sexo comercial da pie a que en algún momento alguien tenga sexo sin condón. Además tomando en cuenta que el consumo de sexo va de la mano con el consumo de alcohol, el riesgo aumenta considerablemente. Más adelante, en la misma entrevista con la intención de indagar qué tan frecuente las mujeres acceden al sexo desprotegido, se le preguntó al mismo hombre:

-... me ha dicho usted que no le gusta usar condón, ¿pero ellas le exigen condón?

- ¡A h, sí!, exigían. Pero yo le decía, ‘bueno, con la que quiere condón yo no me meto', y cuando ellas quieren, pues sí, pues cuando necesitan dinero...

(Hombre con experiencia migratoria, 29 años, Originario de Nichnamtik, Chamula.)

Como se puede apreciar, las condiciones socioeconómicas de las trabajadoras del sexo comercial que atienden a la población migrante, también son un importante factor que genera vulnerabilidad, pues, como hemos visto, las pone en condiciones de anteponer la satisfacción de sus necesidades monetarias a su salud sexual. Esto, aunado a los valores y prejuicios que detectamos en nuestros entrevistados -como el tabú general relativo a charlar sobre sexualidad y el manifiesto desconocimiento de varios de los entrevistados sobre los riegos implícitos en la promiscuidad y el sexo desprotegido- aumenta aún más su condición vulnerable. La incomodidad generada en algunos entrevistados cuando indagamos sobre la sexualidad y su manifiesto desinterés respecto a la prevención son un importante indicio sobre esto:

- ¿Y los hombres que están allá y andaban con mujeres una tras otra o no sé, sabes qué riesgo corre un hombre o una mujer?

- No sé, nunca sé, nunca me interesó, como yo era una de esas personas nunca me importó, pues no sé, la verdad, ni me interesa saber qué es.

- Ah, ¿entonces nunca supiste nada?

- No, no nunca supe, es más, yo no sé nada de esas cosas, no tengo idea.

(Hombre con experiencia migratoria, 26 años, Las Ollas, Chamula.)

Los testimonios son elocuentes en lo que se refiere al desconocimiento del uso del condón. Si no se conocen los riesgos de contraer infecciones de transmisión sexual, el uso de condón no tiene sentido:

- Usted ¿no sabe de alguna protección para que no se contagie de esta enfermedad? [Están hablando del VIH/SIDA].

- No, no.

- ¿No sabe usted sobre el uso del condón?

- No, ni conozco, por eso mismo te digo que no sé.

(Hombre con experiencia migratoria, 43 años, Las Ollas, Chamula.)

Respecto a este desconocimiento acerca de las infecciones de transmisión sexual, en algunas ocasiones los entrevistados admitían conocer algo y un momento después lo negaban. Acerca del SIDA algunos informantes describieron 
vagamente la enfermedad, pero al mismo tiempo negaban tener conocimiento sobre ella:

-...yo te digo que vi muchas personas en mi trabajo o en la calle o en la casa donde vivo, veces veo que están flacos, flacos, pero yo no sé qué tenían, de repente se bajan de peso, se bajan de peso.

(Hombre con experiencia migratoria, 45 años, Las Ollas, Chamula.)

- ¿Entonces no supieron de alguna enfermedad? - No sé, te digo, hay unas compañeras que me comentaban, pero yo no sé de dónde viene esa enfermedad. De hecho me decían que hay hombres que se bajan de peso, flacos, cuando ya están enfermos de SIDA. Eso me dijo una compañera, pero no sé de donde lo supo, me dijo que cuando un hombre anda con muchas mujeres, o una mujer anda con varios hombres le puede contagiar esa enfermedad. Esa enfermedad no tiene curación, me dijo, pero yo no tengo idea.

(Entrevista a mujer con experiencia migratoria, 20 años, Las Ollas, Chamula.)

Con relación a lo anterior, podemos notar que no sólo existe poca información sobre las infecciones de transmisión sexual, sino que los entrevistados consideran a estas infecciones como algo ajeno o, incluso, algo de lo cual no quieren saber. El testimonio siguiente es más que elocuente:

- ¿Pero sabe usted el condón para que sirve?

- Bueno, he escuchado en el radio, pero no sé para qué sirve, quizás lo hayan comentado, pero como nunca me importa, pues la verdad no sé para qué sirve.

(Hombre con experiencia migratoria, 26 años, Las Ollas Chamula.)
Así pues, el manifiesto desinterés de los migrantes chamelas entrevistados hacia los temas de salud sexual, la reticencia a hablar sobre los mismos, la práctica frecuente de alcoholización como forma de esparcimiento y convivencia masculina, la disponibilidad de trabajadoras de sexo comercial que dirigen su oferta a esta población migrante, todos son factores que aumentan la posibilidad de que se incurra en prácticas de riesgo. Sobre esta tendencia opina uno de los entrevistados:

- Ah, pero tus amigos que a veces se metían con mujeres, ¿no te platicaron sobre el condón

- Ni creo que lo conozcan, si lo conocieran estaría bueno, a ellos les viene valiendo, hacen cosas pero no piensan en su familia.

(Hombre con experiencia migratoria, 45 años, Las Ollas, Chamula.)

\section{Roles de género y vulnerabilidad}

Como ya indicamos, las relaciones sexuales con trabajadoras de sexo comercial suelen ser regla, más que excepción. Esto es cierto tanto para hombres solteros como para los casados y así lo confirman los siguientes testimonios:

- ¿Escuchaste allá de prostitución, de mujeres que van a buscar a los hombres para tener sexo?

- Sí en los departamentos todos compran las mujeres $[\ldots]$

- ¿Son los que están solos los que hacen eso?

- No sé, hay quienes tienen su mujer pero compran mujer.

(Mujer con experiencia migratoria, 18 años, Las Ollas, Chamula.)

- ¿Y usted cree que los hombres solos que están allá se animan a tener relaciones con esas mujeres 
la mayoría de las veces o no se animan, dicen "no, yo no quiero"?

- [Carcajada $]$ Nadie dice eso. Bueno, yo... donde vivía había varios apartamentos al frente, eran puros hombres, pero la mayor veces he visto salir mujeres de la puerta.

- ¿Y son hombres casados o son hombres solteros?

- Algunos casados y solteros.

(Mujer con experiencia migratoria, 24 años, originaria de Teopisca, San Cristóbal de Las Casas, Chiapas).

En este sentido, algunos hombres reconocen que involucrarse en prácticas sexuales extramaritales es un hecho inevitable porque es parte de la naturaleza masculina:

-...una mujer es muy diferente de un hombre, una mujer puede estar muchos años sin un hombre pero un hombre es muy diferente, pero hay muchas formas de no estar con una mujer...

- ¿Y usted como le hacía sin su esposa?

- Bueno, pa' que te cuento porque hay cosas que a veces una mujer no entiende.

(Hombre con experiencia migratoria, 45 años, Las Ollas, Chamula.)

- Sí, claro, cómo no. Los hombres las traen a las mujeres. Usted mismo, no dejas de ser hombre.

(Hombre con experiencia migratoria, 60 años, Las Ollas, Chamula.)

De igual manera, aunque algunas mujeres que tienen esposo migrante dijeron desconocer si éste tenía relaciones con otras mujeres al estar lejos, con sus comentarios mostraron dudas respecto a la fidelidad de él, pues consideran que el sexo extramarital es parte de la naturaleza de los hombres:

- ¿Y tu esposo será que no anda con otra mujer aparte de ti?

- Pues tampoco lo sé, si lo hace no lo sé, pero ahorita que estamos acá, su primera mujer está acá y yo estoy acá, pues puede ser que sí, ¿cómo lo voy a saber?, un hombre no puede estar solo. (Mujer con experiencia migratoria, 25 años, Las Ollas, Chamula.)

Algunas mujeres francamente se muestran indiferentes ante el comportamiento sexual de su marido:

- No creo, no sé, la verdad, no creo, de eso no sé, ni me importaría si lo haría, pero con que sepa hacerlo [...] qué le hago. Estando lejos, no sé qué hace, no sé qué haga o qué no haga, qué voy a saber, sabrá él lo que hace.

(Mujer con esposo migrante, 27 años, Las Ollas, Chamula.)

Otras mujeres incluso se muestran felices de que su marido no esté en casa:

- ¿Y si acaso tu esposo regresa, cómo te sentirás, te sientes mejor, te sientes feliz, estando aquí tu familia, tu esposo?

- Para mí es igual, no siento nada [...] Pues para qué, no sé, para que venga aquí a tomar, mejor que esté trabajando lejos [...] no sé, para mí como que me da un poco igual, no hay mucha diferencia en que esté o no esté.

(Mujer con esposo migrante, 22 años, Las Ollas, Chamula.) 
Incluso, una mujer que sabe que su marido se relaciona sexualmente con otras mujeres, parece estar conforme porque considera que cuando él busca otras mujeres no establece ningún compromiso emocional o afectivo. Su testimonio es elocuente:

-...yo nunca lo vi. Y aún cuando ya estaba en el norte mi esposo le pregunté si era cierto que andaba con una mujer cuando trabajaba de taxista, él me dijo que sí pero que no la quería.

[...]

- ¿Y usted ha utilizado condón con él?

- Conmigo no ha utilizado porque no estamos decididos cuantos hijos debemos de tener, pero como me quiere, por eso con otra mujer lo utiliza para no embarazarla, según que dice él.

(Mujer con esposo migrante, 27 años, Las Ollas, Chamula.)

La franqueza del esposo de la entrevistada es excepcional, según los testimonios recabados; sin embargo, es el único hombre que manifiesta preocupación por las consecuencias de su proceder sexual con otras mujeres. Para la mayoría de los entrevistados, hombres y mujeres, el uso de condón en las relaciones maritales o extramaritales no es una opción. Esto a pesar de que como parte del programa gubernamental Oportunidades -en el cual se dan charlas a mujeres sobre salud sexual-las medidas preventivas para infecciones de transmisión sexual se promueven con regularidad en los centros de salud. Es digno de mención que a partir de dicho programa algunos hombres han llegado a concebir este conocimiento como cosa de mujeres:

- ¿Usted alguna vez ha usado condón?

- No, no conozco, no sé para qué sirve. [...] No, pues no tengo idea te digo, yo no estudié, yo no me preparé tanto y no sé qué es eso. Ni la he escuchado, quizás las mujeres sí porque tienen Oportunidades y a veces les platican, en cambio como hombre no conozco.

(Hombre con experiencia migratoria, 45 años, Las Ollas Chamula.)

Del mismo modo, las mujeres expresan que, pese a las pláticas, no les interesa este tema:

$-¿ Y$ usted sabe de alguna enfermedad, de alguna infección?

- Bueno, no sé nada, quizá la promotora o el doctor nos ha dicho de alguna infección, pero yo no me acuerdo, es que soy un poquito tontita.

- Ah, así es, entonces así es, que no te acuerdas nada, no sabes nada, no te cuenta nada tu esposo...

- No, no me cuenta y quizás, te digo, pues no, nunca le tomo importancia.

(Mujer con experiencia migratoria, 22 años, Las Ollas, Chamula.)

Así pues, el desconocimiento o apatía respecto al uso del condón, se combina con las relaciones extramaritales que cómo hemos visto son práctica común entre la población migrante. Esto es frecuente no sólo en el consumo de sexoservicio, pues los esposos que están solos en Estados Unidos, al viajar sin su esposa, tienen la posibilidad de conseguir una nueva pareja. Las mujeres casadas, en cambio, suelen migrar junto con su marido o, las más de las veces, se quedan en casa, en Chamula.

Las mujeres migrantes que se van solteras, frecuentemente, se unen a un hombre, muchas veces, sin saber si éste ya tiene una pareja en su lugar de origen; en otras ocasiones, la mujer se une al hombre sabiendo, incluso, que éste es casado.

\section{7}


- ¿Y dónde conociste a tu esposo?

- Es que vive cerca de donde rentábamos con unas amigas.

- ¿Cómo sabes si ese chavo o ese señor era soltero o casado?

- De por sí era casado, lo sabía, pero así lo acepté, yo soy la segunda.

- Ah, ¿entonces eres la segunda mujer?

- Así como lo oyes.

(Mujer con experiencia migratoria, 25 años, Las Ollas, Chamula.)

De este modo, las relaciones de pareja en donde el hombre migra y la mujer permanece en Chamula, son inestables y endebles. Si el hombre migrante establece una relación extramarital, su esposa que permanece en Chamula verá reducida una parte del apoyo económico que le reportan las remesas y siempre está latente la posibilidad de verse desamparadas totalmente. En esa situación se encuentran tres de las mujeres con experiencia migratoria. Ellas conocieron a sus respectivos esposos en los Estados Unidos y las tres regresaron a México una vez que se embarazaron, para parir. De ellas, una supo desde antes de juntarse con el hombre, que él tenía una primera mujer, sin embargo, aceptó entablar la relación. Otra de las entrevistadas se ha enterado que su pareja, ahora que ella ha regresado a Chamula, ya se ha juntado con otra mujer en Estados Unidos. La tercera entrevistada expresa sospechas de la posible infidelidad de su pareja. Veamos los testimonios de dos de ellas:

- Entonces, ¿por qué te decidiste regresar? - Porque me embaracé y regresé. No quería tener mi bebé allá. Que tal que me muero allá. En cambio aquí en mi casa conozco personas que me pueden atender. $\mathrm{O}$ además, estoy cerca de mi mamá.
- Entonces por eso regresaste, ¿y tu esposo estaba de acuerdo en que regresaras?

- Sí, me dijo que estaba de acuerdo, si quiere que regrese a mi casa.

- Ahora su esposo que está en el Norte, ¿le manda dinero?

- Sí, pero muy poco, porque ya tiene otra mujer.

- Ah, entonces ya tiene otra mujer.

- Así es, así como lo oyes.

- ¿Cómo sabes que ya tiene otra mujer?

- Mi papá me dijo, porque regresé antes que mi papá, me dijo que andaba con otra mujer, 'por eso no te manda bien tu dinero', me dijo mi papá.

(Mujer con experiencia migratoria, 20 años, Las Ollas, Chamula.)

- ¿Tu esposo ya estaba casado antes o es la primera vez que se casa?

- Dijo que es la primera vez o no sé.

- ¿Tienes dudas?

- Sí, porque no sé si tiene su mujer o no.

(Mujer con experiencia migratoria, 18 años, Las

Ollas, Chamula.)

Así, las mujeres esposas de hombres migrantes se encuentran, por un lado, ante la posibilidad de perder apoyo económico de su marido si éste establece una relación extramarital y, por otro lado, enfrentan la posibilidad de contraer una infección sexual transmitida por su cónyuge. Esto, de hecho, ya se ha convertido en realidad en dos de las mujeres entrevistadas, las únicas que señalaron que sí se han practicado el estudio del Papanicolau y quienes además son conscientes de la infidelidad de sus maridos. Ambas presentaron infección por el virus de papiloma humano, implicado en la causalidad del cáncer cervicouterino: 
- ¿Usted ha sacado alguna vez un estudio que se llama Papanicolau?

- Si, ya lo hice dos veces, la primera vez me dijeron que tenía cáncer, y la segunda vez ya no tuve nada.

(Mujer con experiencia migratoria, 27 años, Las Ollas, Chamula.)

- Ah, ¿y usted ha sacado un estudio que se llama Papanicolau?

- [...] varias veces, lo he sacado varias veces, pero... pero estoy enferma.

- ¿Y qué enfermedad te detectaron?

- Yo creo, parece que se llama pólipo, así se llama la enfermedad que me encontraron en el Papanicolau que me sacaron.

- Ah, sí, ¿y qué tratamiento te dieron para que se curara esa enfermedad que tienes?

- Nada, no me dieron nada, dicen que no tiene tratamiento.

- Ah, no tiene tratamiento.

- Lo que hicieron fue que lo sacaron, jme la cortaron!

- ¿Cómo? ¿Cómo que te cortaron?

- "Sí, me la cortaron [...] Pero me costó para recuperarme después de que me hayan sacado... creo que me la cortaron mal.

(Mujer con experiencia migratoria, 29 años, Las Ollas, Chamula.)

Estas dos mujeres que se manifiestan conscientes de la infidelidad de sus maridos y de los riesgos de la promiscuidad sexual, muestran, sin embargo, que la disponibilidad de información no es una medida suficiente. Esta vez fue el virus del papiloma humano, pero pudo ser, también, el virus de la inmunodeficiencia humana, cuya detección depende de una prueba que no es accesible a los habitantes ni física (pues no se ofrece en los servicios de salud locales) ni culturalmente (ya que no existe conciencia real de la posibilidad de ser infectados).

\section{Conclusiones}

\section{Pobreza, migración y vulnerabilidad}

Detrás de la migración ilegal a otros países se encuentra, la mayoría de las veces, la pobreza y la falta de oportunidades para las personas en su propio país. Como hemos visto, la migración internacional en Chamula se deriva de la baja productividad en el campo, los endeudamientos y las ambiciones de conseguir bienes materiales que también son fuente de prestigio. Por ello, dado que las condiciones en el municipio no permiten que todas las familias puedan satisfacer adecuadamente sus necesidades básicas, ni sus anhelos de mejorar su status social y económico, una opción asequible es migrar a los Estados Unidos de América. Quedarse implica asumir las limitaciones del contexto local, pues incluso para los jóvenes indígenas que han logrado terminar la secundaria o la preparatoria, es muy difícil encontrar en el municipio un trabajo que les permita obtener ingresos suficientes para satisfacer sus necesidades elementales, menos aún que les genere un excedente para ahorrar o adquirir bienes materiales como un vehículo o mejorar la calidad de la vivienda.

De esta forma, la pobreza y la falta de oportunidades que conducen a la migración son el primer contexto que genera vulnerabilidad, pues una vez iniciado el proceso migratorio, está latente la posibilidad de incurrir en prácticas de riesgo para su salud sexual y dichas prácticas pueden repercutir entre los familiares que se quedan en la comunidad. 
MIGRACIÓN INTERNACIONAL INDÍGENA

Y VULNERABILIDAD ANTE EL VIH-SIDA.

Migración ilegal, diferencia étnica y vulnerabilidad

Durante el viaje de ida y regreso de Chamula a los Estados Unidos, que implica diversos peligros, los migrantes no suelen involucrarse en prácticas de riesgo para adquirir infecciones de transmisión sexual. Sin embargo, en la vida cotidiana en el lugar destino, la condición de ilegalidad, aunada a la pertenencia étnica, limita de manera notable los espacios de movilidad de los migrantes. Según los testimonios recabados, las actividades de los migrantes chamulas se restringen a tres espacios: su casa, el trabajo y la tienda de autoservicio, y aunque en el trabajo a veces establecen relaciones de amistad con otros grupos de migrantes latinos y mexicanos, en general se mantienen alejados de los espacios que con el tiempo éstos han conquistado.

$\mathrm{Al}$ parecer, aún en el norte los indígenas son discriminados por otros mexicanos, de manera que se reproduce la inequidad y los prejuicios interétnicos que existen en nuestro país, lo que a su vez crea las condiciones para que la principal forma de esparcimiento y desahogo social para los hombres indígenas (y en general para los migrantes de más escasos recursos) sea el consumo de alcohol y el sexo servicio que se ofrece en condiciones sumamente riesgosas.

Por esta razón, consideramos que la poca libertad de movimiento, derivada de la ilegalidad, el bajo nivel económico entre los diversos grupos migrantes y la segregación étnica, constituyen un segundo contexto de vulnerabilidad que se manifiesta en el consumo institucionalizado de sexo servicio y alcohol los fines de semana. La inequidad, manifiesta también en prejuicios interculturales, se expresa en la extremada limitación de la libertad y en la dificultad para generar ámbitos de socialización menos riesgosos.
Resulta hasta cierto punto obvio señalar que durante el proceso migratorio los grupos se enfrentan a circunstancias nuevas que producen cambios en su forma de vivir y pensar. Estos cambios suelen ser acelerados y su impacto puede ser demasiado brusco en la vida de las personas tanto en el lugar de origen como en el de destino; muchas veces ocasionando el efecto de desarraigo cultural en las nuevas generaciones.

En el municipio de Chamula, la migración a Estados Unidos ha generado cambios en ciertos aspectos de la vida y la cultura. Por ello, además de la prosperidad material visible en algunas casas, se escuchan, como una moda, las canciones norteñas y de banda con referencia a aventuras de migrantes, narcotráfico y contrabando, las cuales además conllevan todo un conjunto de imágenes sobre la sexualidad y la mujer que contrastan con el tradicionalismo propio de Chamula.

No sabemos en qué nivel esto esté impactando a la población, pero pensamos que esta nueva cultura que fomenta la ilegalidad, es también resultado de la falta de equidad y es posible que muchos jóvenes -expuestos al desarraigo cultural que nace del contacto intercultural y la falta de opciones económicas en el lugar de origen- la tomen como propia aumentando los índices de criminalidad y generando contextos de vulnerabilidad frente a las infecciones de transmisión sexual.

Por lo pronto, la migración internacional en poco tiempo se ha convertido en un fenómeno cíclico, que tiende a que la vida económica de las familias tenga su base en las remesas y periódicamente los miembros tengan que enrolarse en la aventura de ir, regresar un tiempo $\mathrm{y}$ volverse a ir, lo que ha ocasionado que el 
trafico de migrantes se haya vuelto un negocio sumamente rentable. Sin embargo, debemos destacar que actualmente el municipio, como polo de identidad étnica, mantiene su fuerza y la mayor parte de los migrantes actuales fincan sus anhelos en su tierra y no fuera de ella.

El impacto de la migración en la cultura del municipio es un tema de bastante interés. Por ahora sólo tenemos pistas que parecen indicar el surgimiento de una "cultura migratoria" cuyo desarrollo acelerado puede generar prácticas y representaciones riesgosas respecto a la sexualidad.

\section{Género, inestabilidad familiar y vulnerabilidad}

En Estados Unidos, el nuevo ambiente también está generando cambios importantes. Respecto a las relaciones y roles de género, que son un asunto esencial cuando se reflexiona sobre la salud sexual, identificamos que uno de los cambios es la participación de los hombres en las labores domésticas, sin embargo, al parecer esto no es más que algo transitorio dado que aún son menos las mujeres migrantes y estando ellas lo más probable es que tengan el deber de hacerlas.

Más notable en cambio es el surgimiento de la práctica de cortejo, que aunque brinda a las mujeres la oportunidad de elegir su pareja, algo que generalmente es difícil en el municipio, también se ha suscitado en un contexto donde las relaciones de pareja se vuelven inestables y riesgosas principalmente para la mujer. En este plano, aunque no tenemos un punto inicial de comparación, es claro que la migración internacional afecta la estabilidad de las familias de Chamula debido a que la mayoría de las parejas se ven obligadas a separarse y en el nuevo contexto los hombres tienen bastantes oportunidades para constituir una nueva familia.
De esta manera, el carácter transitorio de la vida migrante no permite cimentar bases firmes en las uniones nuevas y pone en riesgo las uniones que ya existían. En esta situación, las mujeres son las más afectadas, pues ante el fracaso de la relación siempre están expuestas a perder el apoyo económico de sus parejas y enfrentar, en ocasiones incluso sin apoyo de sus familiares, su sobrevivencia y la de los hijos, en condiciones que las hacen susceptibles de muchos tipos de abuso.

Por otra parte, la facilidad que existe en el norte para el sexo extramarital (muchas veces sin uso de preservativo) coloca a las mujeres y sus familias en franca desprotección ante las infecciones de transmisión sexual que pueda contraer el marido durante el proceso migratorio.

\section{Conocimiento preventivo y vulnerabilidad}

El conocimiento sobre salud sexual, aunque tiene deficiencias, existe. Sin embargo, llama la atención el desdén con el que se refiere. Generalmente se expresa lo que se sabe pero inmediatamente se remata el comentario con frases como "pero la verdad no me importa”. Esto quedó plasmado en los testimonios de varios hombres y mujeres. Un hombre incluso ha llegado a considerar que el conocimiento preventivo en salud sexual es cosa de mujeres, lo cual, probablemente, surge porque el programa gubernamental Oportunidades trabaja temas de salud sexual exclusivamente con mujeres.

Por ello, aunque las mujeres de la localidad reciben información preventiva sobre infecciones de transmisión sexual, en las charlas de dicho programa, esta información no es valorada en los testimonios y por lo tanto no está teniendo un verdadero impacto en la población. Por ello, consideramos que una debilidad básica de esta estrategia es que la información no llega a los 
hombres que son quienes más se exponen a prácticas de riesgo en cuanto a la salud sexual. Una propuesta integral debería atender a la población masculina al mismo tiempo que la femenina, recordando que la construcción de género es relacional y para cambiar deben participar ambas partes.

\section{Consumo de alcohol y sexo servicio y vulnerabilidad}

Enmarcados en un contexto general que restringe en grado extremo la libertad de movimiento de los migrantes y su capacidad de interactuar en espacios de socialización menos riesgosos, el consumo de cerveza y la oferta clandestina de servicios sexuales en los domicilios de los migrantes es algo que sucede todos los fines de semana, justo cuando los migrantes han recibido el pago de su trabajo. Como pudimos constatar, estas dos prácticas son normales y frecuentes entre los migrantes casados y no casados y alrededor de ellas se manifiestan diferentes factores tanto económicos como culturales que generan prácticas riesgosas para la salud sexual.

No conocemos las condiciones laborales de las sexoservidoras - las cuales supimos que muchas veces son latinas y es posible que sean mujeres explotadas por su condición ilegal-, pero constatamos que a pesar de tener una política de proporcionar un preservativo a su cliente, muchas veces incurren en el sexo desprotegido para negociar más dinero. Esta accesibilidad a prácticas de riesgo de las sexoservidoras -derivada al parecer de sus condiciones socioeconómicas bajas y el deterioro físico producido por la edad (si no son jóvenes son más flexibles en sus tratos) - se combina no sólo con el consumo de alcohol que, consideramos, comúnmente relaja la prudencia de las personas, sino aún más gravemente con el prácticamente nulo interés que los migrantes manifiestan respecto a su salud sexual, lo cual hace que ni siquiera exista un real sentido del peligro. La mayoría de los hombres negaron que usaran condón y los testimonios muestran que para ellos no es una opción culturalmente plausible.

Así, las condiciones de las mujeres sexo servidoras que acceden a prácticas de riesgo, el consumo de alcohol entre los migrantes, falta de interés de estos por su salud sexual e indiferencia ante el uso del condón - $-\mathrm{y}$ en ocasiones también la declarada preferencia por las relaciones desprotegidas-convergen en relaciones sexuales de alto riego para la salud sexual, lo cual hace evidente que aun las prácticas de consumo de alcohol y sexo servicio, que podríamos considerar individuales, están condicionadas por un contexto que genera vulnerabilidad.

Vulnerabilidad de los migrantes y su comunidad ante el VIH-SIDA

Los testimonios que hemos citado muestran de diferentes maneras cómo el proceso migratorio hace vulnerables a los migrantes chamulas y a sus familias. No existen datos oficiales sobre la presencia del VIH-SIDA en Chamula, esto en gran medida por que las personas no se han hecho la prueba y no existe una accesibilidad ni física ni cultural a ella. A pesar de esto, informalmente supimos que en la región se han presentado algunos casos de SIDA en su fase terminal padecidos por personas con experiencia migratoria. Es obvio que el principal factor es el sexo extramarital riesgoso que practica la población migrante. Las mujeres de la comunidad, quienes no podrían negociar el uso de condón u otro tipo de protección con sus esposos (en caso de pensarlo, lo cual resulta improbable), se ven de esta forma expuestas a la posibilidad de un fuerte aumento en la presencia del VIH que cómo sabemos tiene 
un largo periodo en que permanece latente sin que se manifieste el síndrome que debilita el sistema inmunológico. En este artículo, hemos tocado temas importantes que requieren más investigación y discusión teórica. Esperamos que la información presentada aliente investigaciones en las que se discuta teóricamente la temática y se promuevan otras cuyo propósito sea reducir la vulnerabilidad de los migrantes.

\section{Notas}

${ }^{1} \mathrm{El}$ presente trabajo surge de la información obtenida en el marco del proyecto "Migración y riesgo de infección por VIH en Los Altos de Chiapas", que fue coordinado por la doctora Graciela Freyermuth, investigadora titular de Centro de Investigaciones y Estudios Superiores en Antropología Social del Sureste (CIESAS-Sureste). Los autores suscritos participamos como investigadores y coautores del proyecto. El financiamiento de las actividades lo proporcionó el Consejo Estatal de Población en Chiapas (COESPO) durante el período de enero a septiembre de 2005.

${ }^{2}$ Chiapas se encuentra en el extremo sur de México en donde hace frontera con Guatemala. El estado se divide oficialmente en nueve regiones socioeconómicas: I. Centro, II. Altos, III. Fronteriza, IV. Frailesca, V. Norte, VI. Selva, VII. Sierra, VIII. Soconusco y IX. Istmo-costa (véase www.chiapas.com.mx/economia/economicas2. html). Los Altos es una región montañosa de clima predominantemente templado subhúmedo, ubicada en la parte más alta del Macizo Central del estado (véase Farrera, 1998 y Viqueira, 2002a). Oficialmente, la región está conformada por 18 municipios, la mayoría de los cuales han estado ligados entre ellos cultural y económicamente a lo largo de la historia. En términos generales la región se caracteriza por el predominio de población maya, principalmente de habla tsotsil y tseltal, que ha mantenido una estrecha interacción social y económica con algunos pueblos y ciudades habitadas principalmente por mestizos. San Cristóbal de las Casas es la principal ciudad de la región. Para una introducción a la historia y complejidad actual de la vida en Los Altos, véase Viqueira (2002b).
E T

${ }^{3}$ Los motivos y las características de estos flujos migratorios han sido en condiciones y circunstancias diferentes a lo largo del tiempo: obligados por endeudamiento en el sistema de "enganche", por decisión propia ante las malas condiciones económicas y por problemas políticos y religiosos.

${ }^{4}$ Incluimos también la entrevista con una mujer tsotsil originaria del municipio de Teopisca (que forma parte de la región Altos), quién vivió en contacto estrecho con migrantes del municipio de Chamula y nos dio importante información para conocer el proceso migratorio y las condiciones que ponen en riesgo la salud sexual de los migrantes indígenas.

${ }^{5}$ Véase también Herrera y Campero (2002), MatickaTyndale (2001), Rodríguez (2001), Delor y Hubert (2003), Shepard et al. (2002).

${ }^{6}$ Estas últimas, además, al regresar, dejaron a sus maridos trabajando en Estados Unidos. Una de ellas fue entrevistada en San Cristóbal de las Casas, es originaria de Teopisca y su marido de Huixtán (ambos municipios pertenecientes a la misma región). Las otras tres son originarias de la comunidad de Las Ollas, Chamula; una vive en casa de los suegros y las otras viven con sus padres.

${ }^{7}$ Las cuatro viven en casa propia, aunque una de ellas vive en una casa contigua a la de su suegra y otra tiene su casa junto al terreno del suegro a quien ella y las otras esposas de los hijos de él (también migrantes) llaman "nuestro papá".

${ }^{8}$ Once entrevistas fueron realizadas por Sebastiana Pale Pérez, dos por Sergio Meneses y dos por Juan Carlos García Sosa. Catorce entrevistas se realizaron en la localidad de Las Ollas, Chamula y dos en San Cristóbal de Las Casas. Todas fueron grabadas en audio.

${ }^{9}$ De este total de habitantes, 32029 son hombres y 35056 son mujeres. En cuanto a la migración en el municipio las estadísticas que presenta el Conteo del INEGI 2005 muestran un serio subregistro. Sólo se registraron 266 migrantes de los cuales 42 están en otra entidad, 13 en Estados Unidos, 2 en otro país y del resto, 209, su residencia no fue especificada. Nosotros en 100 casas de 369 con que cuenta la comunidad de Las Ollas, Chamula, registramos, en el mismo año, 117 migrantes de los cuales 80 residían en Estados Unidos.

${ }^{10}$ Para un análisis de las condiciones que han generado el aumento de la migración en Chiapas véase Pickard (2005).

${ }^{11}$ Ésta puede ser la razón de que en uno de los barrios 
de la localidad, el que lucía más pobre, registramos pocos migrantes internacionales.

${ }^{12}$ Principalmente en los estados de Florida, Georgia y Alabama.

${ }^{13}$ En nuestra encuesta a 100 casas de la comunidad de Las Ollas, registramos un total de 80 migrantes en Estados Unidos, 57 hombres $(71.2 \%)$ y 23 mujeres $(28.8 \%)$.

${ }^{14}$ Por referencia de un migrante michoacano, sabemos que en muchos lugares de Estados Unidos los latinos reproducen el prejuicio racista hacia los grupos étnicos que existen en sus países. Una forma común de llamarlos es "oaxaquitas" o "guatemalitas", palabras en las que el tono despectivo es evidente.

${ }^{15}$ En nuestra encuesta a 100 casas de la comunidad de las Ollas registramos que del total de migrantes nacionales e internacionales, 117,110 se comunican con constancia y 81 además mandan ayuda a la familia. La mayoría de los migrantes internacionales mantiene contacto telefónico con sus familias.

${ }^{16}$ Según el testimonio de este migrante michoacano, existen diferentes tipos de trabajadoras del sexo comercial: las manejadas por hombres negros, las manejadas por estadounidenses y las manejadas por latinos, también llamadas "treinteras".

\section{Bibliografía}

AIDS-Vancouver, Definición de vulnerabilidad en: www.redmex.org/redmexicana/AIDSVancouver Bronfman, M; Leyva, R; Negroni, M., 2005, Movilidad poblacional y VIH/SIDA. Contextos de Vulnerabilidad en México y Centroamérica. INSP, México.

Delor Francois; Michel Hubert, 2003, Un ré-examen du concept de "vulnérabilité" pour la recherche et la prévention du VIH-SIDA, Observatoire du Sida et des Sexualités, Centres d'Etudes Sociologiques, Belgique, en: www. fusl.ac.be/observatoire.

Ferrara C., Norma, 1998, "Estrategias de reproducción socioeconómica en las comunidades indígenas de los Altos de Chiapas" en Anuario de Estudios Indígenas VII, UNACH-IEI, San Cristóbal de las Casas, Chiapas, México.

Herrera Cristina, Lourdes Campero, 2002, "La vulnerabilidad e invisibilidad de las mujeres ante el VIH-SIDA" en Salud Pública de México, noviembre- diciembre, Vol.44, Num. 6, Cuernavaca, Morelos, México, pp. 554-564.

INEGI, 2005, II Conteo nacional de población y vivienda 2005, en www.inegi.gob.mx

Izazola, J.; Astrola, L.; Beloqui, J.; Bronfman, M.; Chequer, P.; Zacarías, F., 1999, “Avances en la comprensión del VIH/SIDA: una visión multidisciplinaria" en Izazola, J.A. ed. El sida en América Latina y el Caribe: una visión multidisciplinaria, FUNSALUD, México.

Mann, Jonathan, 1998, "Derechos humanos y SIDA: el futuro de la pandemia" en Letra $S, 1$ de octubre.

Maticka-Tyndale Eleonor, 2001, "Twenty Years in the AIDS Pandemic: A Place for Sociology", Current Sociology, Vol. 46, Num. 6, pp. 13-21.

ONUSIDA, 2002 Los jóvenes y el VIH/SIDA. Una oportunidad en un momento crucial. UNICEF, ONUSIDA y OMS.

Pickard, Miguel, 2005, Entre fuegos cruzados: Los migrantes mesoamericanos en su travesía hacia el norte. Informe especial, Programa de las Américas del Internacional Relations Center, Silver City.

Proyecto "Migración y SIDA en Centroamerica, México y Estados Unidos” en www.ciss.insp.mx/ migracion

Rodríguez, Jorge, 2001 Vulnerabilidad y grupos vulnerables: un marco de referencia conceptual mirando a los jóvenes, Serie población y desarrollo, CEPAL-ECLAC, Chile: ONU.

Shepard Margaret P.; Allen J. Orsi; Margaret M. Mahon; Ruth M. Carroll, 2002, "Mixed-methods research with vulnerable families" en Journal of Family Nursing, USA, Vol. 8, No. 4, pp. 334-352.

Théodore, Florence; Juan Pablo Gutiérrez; Pilar Torres y Gabriela Luna, 2004, "El sexo recompensado: una práctica en el centro de las vulnerabilidades (ITS/ VIH/SIDA) de las jóvenes mexicanas" en Salud Pública de México, marzo-abril, Vol. 46, No. 2, pp. 104-112.

Viqueira, Juan Pedro, 2002a, "Chiapas y sus regiones" en Viqueira, Juan Pedro y Mario Humberto Ruz (eds.), Chiapas. Los rumbos de otra historia, UNAMCIESAS, México.

Viqueira, Juan Pedro, 2002b, "Los Altos de Chiapas: Una introducción general” en Viqueira, Juan Pedro y Mario Humberto Ruz (eds.), Chiapas. Los rumbos de otra historia, UNAM-CIESAS, México. 